\title{
FLIPPED LEARNING EXPERIENCE IN BUILDING ENGINEERING STUDIES
}

\author{
César Porras Amores, David Caballol Bartolomé, Mónica Morales Segura, \\ Jorge Diaz Guerra, Fernando Magdalena Layos, Julián García Muñoz \\ IEG Actitud Constructiva. Universidad Politécnica de Madrid (SPAIN)
}

\begin{abstract}
In the School of Building Engineering of the Universidad Politécnica de Madrid (UPM), lectures have identified several problems that are related to student learning. Among others we can highlight the abandonment of studies, the high absenteeism and the high compartmentalization of knowledge. There are many situations in which the knowledge acquired by students in a specific subject is only applied to pass the subject and it is forgotten at the end of the semester. In order to solve the issues, a group of lectures from different disciplines have cooperatively prepared some subjects through the Flipped Classroom model. The work included in this paper were developed by several members of the "Actitud Constructiva" UPM Innovative Education Group. The work has been supported by the "Transversal Knowledge through flipped classroom" educational innovation.
\end{abstract}

Keywords: Absenteeism, Innovation, Flipped classroom, Teaching quality, Educational video.

\section{INTRODUCTION}

Previous studies show that in university education there is an excess of compartmentalization [1]. In the School of Building Engineering of the Universidad Politécnica de Madrid (UPM), lectures have identified several problems that are related to student learning, among others we can highlight the abandonment of studies, high absenteeism and high compartmentalization of knowledge. On many occasions, the knowledge acquired by students in a specific subject is only applied to pass the subject and it is forgotten at the end of the semester. When the student faces new subjects, he has difficulty extrapolating the knowledge previously learned. This fact implies that the lecture must "start from scratch" as if the skills and knowledge learned no longer existed or had no relationship. Therefore, it is important to remember that learning is a continuous process that should not end once a certain subject has been passed [2]. The excessive compartmentalization of knowledge greatly damages both the lecture and the student. On the one hand, the lecture needs to spend time re-explaining concepts so that the student remembers previous skills or knowledge, which are necessary to deepen or advance in a certain task. On the other hand, the student receives another time (sometimes in a hurry) the basic knowledge and / or skills that are supposed to be consolidated in another previous subject but that is not able to relate to the new subject. In addition, the student has less time and dedication on the part of his lecture for the tasks and knowledge that will really allow him to acquire the skills of the new subject. In order to solve the issues previously raised, several lectures from different disciplines have cooperatively prepared several subjects through the Flipped Classroom model. The work included in this paper has been carried out by several members of the "Actitud Constructiva" UPM Innovative Education Group and has been supported by the "Transversal Knowledge through flipped classroom" educational innovation project.

The Flipped classroom is a teaching method whose main objective is that the student assumes a much more active role in his learning process than the one he had traditionally occupied. Broadly speaking, it consists in the student studying the theoretical concepts for himself through various tools that the lecture puts at his disposal [3]. Through a greater involvement of the student and a more individualized treatment by the lecture, we can try to alleviate the problem of absenteeism and abandonment. Although the flipped classroom method seems simple, it requires careful preparation to be really effective [4]. There are many works in the literature applying the flipped classroom method using different methodologies and resources [5], [6], [7], [8], [9]. The great diversity that exists shows that the flipped classroom is much more than recording videos to replace the master classes [10]. Considering the above, several lectures from different disciplines of the School of Building Engineering (Spanish acronym: ETSEM) have projected, organized and prepared the teaching material necessary to teach their subjects through the flipped classroom pedagogical model with a multidisciplinary 
approach. The proposal aims to improve the quality of teaching in various subjects of Degree and show students that the reality of the concepts studied is closely interrelated.

\section{METHODOLOGY}

The main objective of the work is to ensure that the students of the degree subjects "Construction of Steel Structures" and "Construction Materials 1" are more motivated and involved to make them his learning more attractive and deep. It should be noted that the subjects chosen are taught both in the "Building Engineering" degree and in the "Building Engineering and Administration and Business Management" double degree studies, however both are taught in different courses. Specifically, the subject of "Building Materials 1" is taught in the first course while the subject of "Construction of Steel Structures" is taught in the second course. The case submitted presents an extremely interesting approach since the disciplines of "Construction" and "Materials" are closely related, being necessary to handle concepts of both subjects for the correct understanding of these.

The flipped classroom can be implemented using different strategies or resources. Among the great diversity that exists, some examples are: the visualization of tutorial or explanatory videos, teaching texts, graphic schemes, problem solving, educational websites, gamification, challenge-based learning and the Moodle tele-teaching platform. Given the impossibility of applying all the resources found during the project, specifically those considered most appropriate are implemented. Specifically, the teaching resources and materials they are developing are the following:

- Lesson modules within the Moodle tele-teaching platform.

- Teaching texts, schemes and real cases.

- Explanatory videos.

\section{RESULTS}

This section includes the details of the teaching resources developed and implemented in the subjects described in the methodology section, as well as their assessment. Similarly, the project monitoring plan is described as well as the expected measurement of results once the semester ends.

\subsection{Lesson modules within the Moodle tele-teaching platform}

Several itineraries with the "lesson module" offered by the Moodle tele-teaching platform were developed for student's navigation. When the student goes into the module reads a short text that explains the necessary concepts to understand the lesson. The concepts are explained by using text, images, graphics and diagrams. When possible, the same images, graphics and schemes used in other subjects from other lectures are used with the intention of emphasizing their interrelation between subjects.

So, each page of the module is dedicated to an important concept which is considered important. At the end of the explanation the student has to do a small exercise in order to demonstrate that the concepts have been properly understood. When the student properly understood the exercise, the student progressively goes on to other pages until the module is completely overcome. On the contrary, when the student makes a mistake, the student is driven to another new page into the same module where the same concept is presented but in a different way. Finally, the student makes another small exercise in which needs to demonstrate that the concepts have been properly understood.

The structure of exploring scenarios and decision trees developed in the lessons aims to give students several opportunities to understand the concepts. It also tries to adapt (as much as possible) to their different learning styles. On the other hand, the decision tree system has a series of limited ramifications that once exceeded retours the user to the home page. If the lesson module is not overcome by the student, the lecture has to assist the student.

Although the lesson module system allows monitoring the student progress (number of attempts, time needed, mistakes made ...), we have decided not to use it as an evaluation method. In this way we convey to the student that the only important thing is to understand the concept and to know how to apply it. This resource has been adapted to adapt the learning to the predisposition, dedication and interest of the student. 


\subsection{Teaching texts, schemes and real cases}

The combination of teaching texts, graphic diagrams and illustration of real cases is intended to relate important concepts which are represented in real cases. Fig 1 shows an example of one of the documents prepared for the subject "Construction of Steel Structures" where the triangulated beams are explained. The concepts and explanations are included in the text (left) and the real case of triangulated beam is in the right of the figure.

\footnotetext{
VIGAS TRIANGULADAS PESADAS Y VIGAS VIERENDELL CRIPCIÓN Y CARACTERÍSTICAS RESISTENTES.

i vigas trianguladas pesadas también se las llama vigas de celosía pesadas para asi poder in e ellas a un caso particular de viga de celosía pesada, como es la viga Vierendell.

erencia de las vigas trianguladas ligeras, en las trianguladas pesadas rara vez se puede ireciar el esfuerzo de flexión en las barras, siendo necesario que todas sus barras se tengar ita los esfuerzos de flexión y cortante además de los de tracción o compresión. otivo mas común es que habitualmente soportan cargas grandes y que no coinciden tamente con el eje de los nudos de la estructura.

stas grandes estructuras es habitual necesitar de una gran rigidez en sus uniones internas.

ANDO SE USAN LAS VIGAS DE CELOSÍA PESADAS?.

rigas de celosía pesadas nos permiten disminuir el peso de la estructura y facilitan el paso laciones a través de sus grandes espacios abiertos, por lo que normalmente es adecuado s is siguientes circunstancias:
}

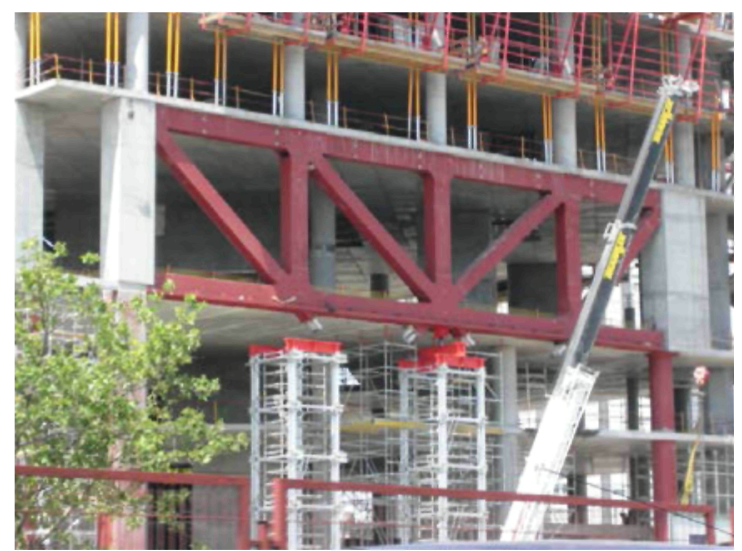

Figure 1. Teaching document of the subject "Construction of Steel Structures"

The real cases are combined with supplementary information explaining the concepts developed in the text and the peculiarities of the real case.

\subsection{Explanatory videos}

The lesson module resource explained above is being supplemented with explanatory videos. This is intended to alternate the methodology and to motivate students more. In addition, we try to ensure that the student is aware of the necessary interdisciplinary knowledge when addressing complex concepts. As an example, when a student expects to see an explanatory video of their well-known regular lecture, the lecture of another discipline is found explaining specific concepts explained in another subject, showing the student the close relationship between both subjects.

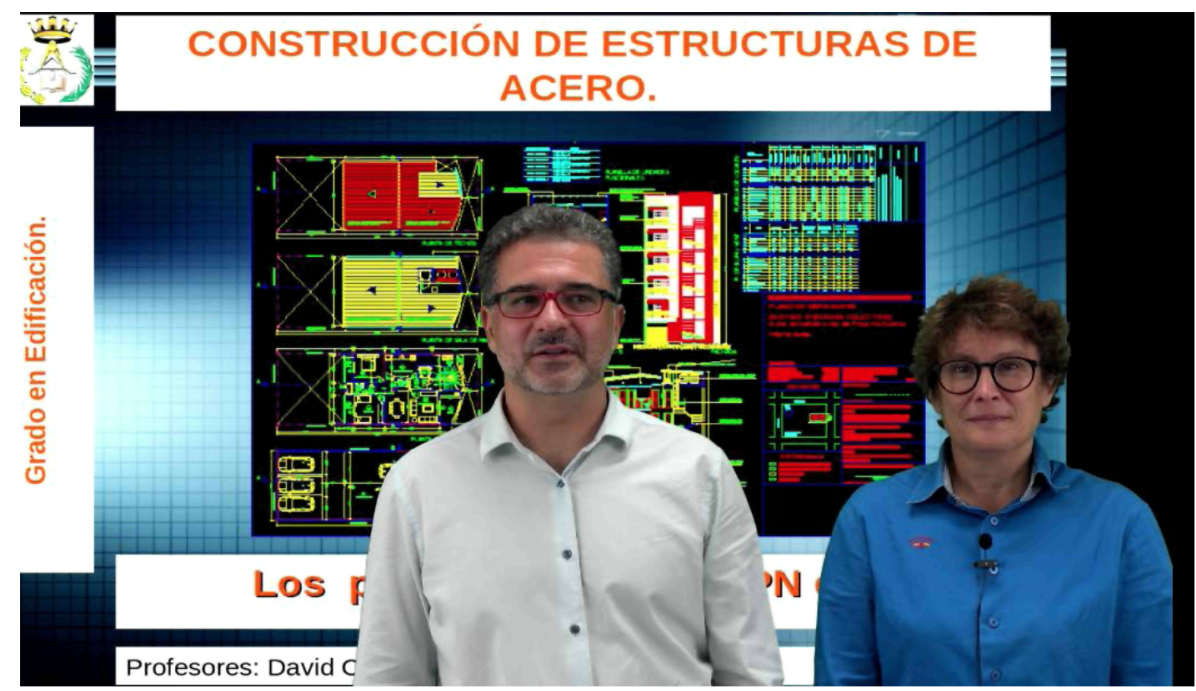

Figure 2. Explanatory video for the subject "Construction of Steel Structures"

The videos are sometimes embedded in the virtual classroom or directly in the book module of Moodle. The book module is used within the virtual classroom as a multi-page resource, it looks similar a book. This resource allows us to have a clear structure through main chapters and sub chapters. Teaching texts, diagrams, graphics, multimedia materials (videos) and animations (flash type) are incorporated into the chapters and sub-chapters. As noted in the examples of resources 
mentioned above, we have focused on providing visual stimuli that are attractive and emphasize the concept of transversal knowledge. It is expected that the visual approach provided will be more easily internalized by most students.

\subsection{Monitoring and evaluation of the project}

During the monitoring of the project and the measurement of results, the following information is expected to be collected:

- Qualifications of the activities done in class. This information will allow to estimate if there has been an improvement in academic results. In this case the evidence of achievement would consist of an improvement in the qualifications of students.

- Both satisfaction and effectiveness surveys of the resources applied. At least two different types of surveys are planned:

- Type 1: Satisfaction surveys. This information will show the degree of satisfaction of the students with the methodology applied. In addition, if this information is compared with the information from other courses in which the same lecture has not applied the methodology, it is possible to know its degree of effectiveness. In this case, the evidence of achievement would consist of an improvement in the assessment and satisfaction from students.

- Tipo 2: Effectiveness surveys. For example, the students will be asked about the fact that the lectures of other subjects appear in the videos or about the fact that several teaching resources have been shared between several subjects. This information will provide information about their general opinion and if they have been able to understand the interrelation between concepts and the necessity of continuity of their learning process.

- Data of both absenteeism and abandonment. This information will reveal the interest and motivation, the students have for the subject. In addition, if this information is compared with the information from other courses in which the same lecture has not applied the methodology, it is possible to know its degree of effectiveness. In this case the evidence of achievement would consist of being able to offer specific data about the decrease in abandonment and/or absenteeism in the subjects involved.

\section{CONCLUSIONS}

Now the conclusions are of a general nature since the experience is being applied.

The lectures rely on the effectiveness of the flipped classroom method. Students show a better attitude to watch videos or to read texts with images from home instead of taking notes or receiving master speeches in class. In addition, they can reread the texts, navigate through different online itineraries (ramifications) or watch the videos several times, until the concept is clear, or they find specific doubts that they can later ask their lecture. Similarly, during the class time, the lecture devotes much more to those students who have more difficulties and need more support. In short, the method helps students become more involved with their learning.

The educational innovation project carried out has favored teaching coordination among lectures and it has served to learn from the different approaches of each lecture. The team of lectures who participated in the project considers that the experience has been enriching and rewarding. When you look to another lecture who explains the same concept in a different way than you usually use in your class, our minds open to a new options, examples and methods that you didn't know.

The fact that lectures acquire the ability to show the same concept in different ways is considered very useful to face the different learning styles of students.

The lecture can learn more about the teaching program of other subjects, helping him to make adjustments and improvements in his subject that leads to an improvement in the quality of his teaching. In addition, the student is made aware of the necessary interdisciplinarity when addressing complex concepts. As an example, when a student expects to see an explanatory video of their wellknown regular lecture, the lecture of another discipline is found explaining specific concepts explained in another subject, showing the student the close relationship between both subjects.

It is expected that the teaching material developed in this paper will be useful in other subjects of the School of Building Engineering as well as with other subjects of the U.P.M. 


\section{ACKNOWLEDGEMENTS}

This study has been carried out as part of the IE1819.5403 educational innovation project founded by Universidad Politécnica de Madrid.

\section{REFERENCES}

[1] Rodamilans, M.; Gómez-Catalán, J.; Barenys, M.; Llobet, J. M.; Pubill, D.; and Quirante, J. (2018). Actividades de integración de conocimientos en el Grado de Farmacia. Aplicación en la asignatura de toxicología. Ars Pharmaceutica (Internet), 59(2), 99-107.

[2] Rodamilans, M.; Cambras, T.; Gómez-Catalan, J.; Mitjans Arnal, M.; Llobet, J. M.; Moreno, J. J.; Teixidó, E.; Vinardell Martínez-Hidalgo, M. P.; Barenys, M. and Diez, A. (2010). La coordinación entre profesores de fisiología y toxicología: un caso práctico en la Facultad de Farmacia de la Universidad de Barcelona.

[3] Berenguer-Albaladejo, C. (2016). Acerca de la utilidad del aula invertida o flipped classroom.

[4] Griffiths, L.; Villarroel, R.; and Ibacache, D. (2016). Implementación del Modelo de Aula Invertida para el aprendizaje activo de la programación en ingeniería. In XXIX Congreso Chileno de Educación en Ingeniería SOCHEDI.

[5] Alba, J.; Torregrosa, C.; Vidal, A.; and Del Rey, R. (2016). Flipped teching en Física del grado de Ingeniería de Sistemas de Telecomunicación, Sonido e Imagen. Primeros resultados. In Universitat Politècnica de València Congreso IN-RED.

[6] Artal-Sevil, J.S.; Romero, E. and Artacho, J.M. (2017) "Quick surveys in classroom. mobile phone, a powerful teaching tool". INTED17 Proceedings of the 11th annual International Technology, Education and Development Conference, Valencia, IATED Academy, pp. 9282-9291.

[7] Bain, K. (2006) "Lo que hacen los mejores profesores universitarios", Valencia, Publicaciones de la Universidad de Valencia.

[8] Fita, I.; Monserrat, J.F. and Moltó, G. (2017). "Aula Inversa: una oportunidad para el desarrollo de compentencias trasversales. Actas del Congreso In-Red 2016.

[9] Gutiérrez, O. and Vicente, J. (2017) "Un año de FLIP: corrigiendo errores". Actas del Congreso InRed 2016.

[10] Morera, I. (2017) "Hacia la clase inversa. Una experiencia de aprendizaje de la Química y de Desarrollo de Competencias en el primer curso de Grado de Ingenierías". Actas del Congreso InRed 2016.

[11] Peña, B.; Zabalza, I.; Usón, S.; Llera, E. M.; Martínez, A. and Romeo, L. M. (2017). Experiencia piloto de aula invertida para mejorar el proceso de enseñanza-aprendizaje en la asignatura de Termodinámica Técnica. Red 2017. III Congreso Nacional de innovación educativa y de docencia en red. (pp. 583-206). Editorial Universitat Politècnica de València. 